\title{
Communication
}

\section{PDZ-Containing Proteins Targeted by the ACE2 Receptor}

\author{
Célia Caillet-Saguy * and Nicolas Wolff *
}

Unité Récepteurs-Canaux, Institut Pasteur, UMR CNRS 3571, 75015 Paris, France

* Correspondence: celia.caillet-saguy@pasteur.fr (C.C.-S.); nicolas.wolff@pasteur.fr (N.W.)

check for

updates

Citation: Caillet-Saguy, C.; Wolff, N. PDZ-Containing Proteins Targeted by the ACE2 Receptor. Viruses 2021, 13, 2281. https://doi.org/10.3390/ v13112281

Academic Editors: Parikshit Bagchi and Anupam Mukherjee

Received: 23 July 2021

Accepted: 10 November 2021

Published: 15 November 2021

Publisher's Note: MDPI stays neutral with regard to jurisdictional claims in published maps and institutional affiliations.

Copyright: (c) 2021 by the authors. Licensee MDPI, Basel, Switzerland. This article is an open access article distributed under the terms and conditions of the Creative Commons Attribution (CC BY) license (https:// creativecommons.org/licenses/by/ $4.0 /)$.

\begin{abstract}
Angiotensin-converting enzyme 2 (ACE2) is a main receptor for SARS-CoV-2 entry to the host cell. Indeed, the first step in viral entry is the binding of the viral trimeric spike (S) protein to ACE2. Abundantly present in human epithelial cells of many organs, ACE2 is also expressed in the human brain. ACE2 is a type I membrane protein with an extracellular N-terminal peptidase domain and a C-terminal collectrin-like domain that ends with a single transmembrane helix and an intracellular 44-residue segment. This C-terminal segment contains a PDZ-binding motif (PBM) targeting protein-interacting domains called PSD-95/Dlg/ZO-1 (PDZ). Here, we identified the human PDZ specificity profile of the ACE2 PBM using the high-throughput holdup assay and measuring the binding intensities of the PBM of ACE2 against the full human PDZome. We discovered 14 human PDZ binders of ACE2 showing significant binding with dissociation constants' values ranging from 3 to $81 \mu \mathrm{M}$. NHERF, SHANK, and SNX27 proteins found in this study are involved in protein trafficking. The PDZ/PBM interactions with ACE2 could play a role in ACE2 internalization and recycling that could be of benefit for the virus entry. Interestingly, most of the ACE2 partners we identified are expressed in neuronal cells, such as SHANK and MAST families, and modifications of the interactions between ACE2 and these neuronal proteins may be involved in the neurological symptoms of COVID-19.
\end{abstract}

Keywords: SARS-CoV-2; ACE2; host factors; binding assay; PDZ domain

\section{Introduction}

Three human coronaviruses have appeared since the early 2000s and caused epidemics: SARS-CoV (2003), MERS-CoV (2012), and finally SARS-CoV-2 (2019). However, only SARSCoV-2 has become a pandemic in a few months.

SARS-CoV-2 is a $30 \mathrm{~kb}$ RNA virus that belongs to the betacoronavirus genus and must enter a host cell in order to be able to replicate. The first step in this process is therefore the entry of viral material into the cytoplasm after passing through the cell membrane. The entry step begins with the attachment of the viral particle to the cell surface. This is based on the interaction between the spicules on the surface of the viral particle (spike protein $S$ of SARS-CoV-2) and the glycoprotein angiotensin-converting enzyme 2 (ACE2) which acts as an entry receptor [1]. After attachment to ACE2, the viral protein $S$ is cut into two parts (S1 and S2) by the transmembrane serine protease 2 (TMPRSS2), which is present on the surface of the host cell [2]. Then, furin cleaves the S2 region (S2') to start conformational changes for fusion between the viral envelope and the plasma membrane of the host cell. Therefore, the "fusion peptide", from residues 816 to 857 of protein S [3], is exposed for insertion into the host cell membrane. There follows a gathering between the envelope of the virus and the cell membrane, both formed by a lipid bilayer which will therefore fuse [4]. In a second ACE2-dependent route, the virus can also enter by endocytosis by the cathepsin-L pathway. Cathepsin $\mathrm{L}$ is ubiquitously expressed in mammalian cells and cleaves the S2' and activates the fusion between viral and endosomal membranes, leading to the release of the viral RNA into the host cell cytoplasm [5] where the virus replicates [6].

The presence of the ACE2 viral receptor is a major determinant of the specific recognition between the virus and the host. SARS-CoV-2 can therefore infect human cells 
expressing ACE2. The expression profile of ACE2 is broad. The highest expression levels of ACE2 are found in the small intestine, testis, kidneys, heart, thyroid and adipose tissue; intermediate in the lungs, colon, liver, bladder and adrenal glands; and lowest in the blood, spleen, bone marrow, brain, blood vessels and muscle [7]. Symptomatic patients with SARS-CoV-2 infection are often reported as having fever, cough, nasal congestion, fatigue and other signs of an upper respiratory tract infection, which can develop into acute respiratory distress syndrome (ARDS) with a low survival rate [8]. Furthermore, ACE2 is essential to the regulation of the renin-angiotensin-aldosterone system (RAAS), which is a main regulator of blood pressure as well as fluid and electrolyte homeostasis.

ACE2 is a glycosylated integral membrane protein of 805 residues with a large Nterminal ectodomain (residues 18-740), a transmembrane domain of 21 residues (residues 741-761) and a short cytoplasmic C-terminal region (residues 762-805) containing a PDZ (PSD-95/Dlg/ZO-1)-binding motif (PBM) at the C-terminal extremity (residues 803-805; sequence-TSF $\mathrm{COOH}$ ) [9] (Figure 1A). This PBM of class I with the motif sequence (S/T)$\mathrm{X}-\Phi_{\mathrm{COOH}}$, where $\mathrm{X}$ is any residue (position -1 ), and $\Phi$ is a hydrophobic residue (last position 0) (Figure 1B), is enabled to bind to other proteins through their PDZ domains. The affinities of a FITC-labeled C-terminal peptide of ACE2 796-805 were previously measured for eight PDZ domains by fluorescence polarization assays [10]. Three PDZ domains, the first PDZ domain (PDZ1) of NHERF3 and the PDZ domains of SHANK1 and SNX27, were found to bind to the ACE2 PBM peptide. However, only 8 of 272 PDZ expressed in the human proteome (the PDZome) were tested in this study. Recently, ACE2 was also shown to interact with NHERF1 PDZ domains enhancing the ACE2 membrane residence, and consequently increasing the ACE2-mediated SARS-CoV2 cell entry [11].

A

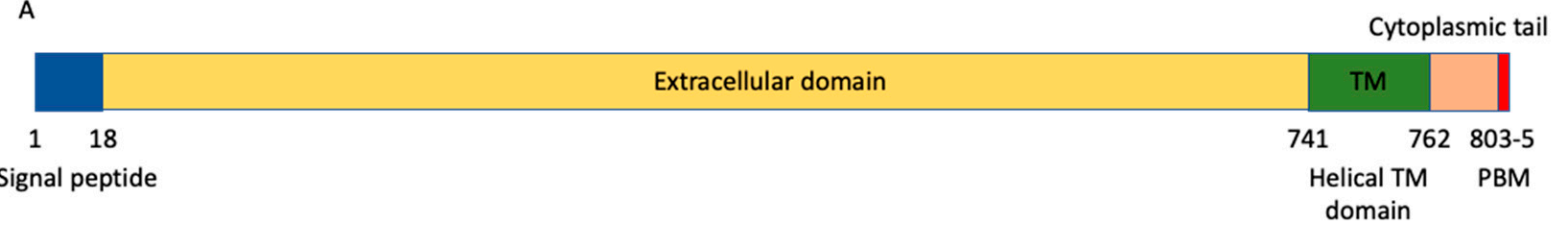

B

Cytoplasmic tail (762-805)

-FTGIRDRKK KNKARSGENPYASIDISKGENNPGFQNTDDVQTSF

C

PBM peptide (794-805)

Biotine-(PEG3)-GFQNTDDVQTSF

Figure 1. ACE2 domain organization. (A) Schematic domain organization of the ACE2 protein. (B) Sequence of the cytoplasmic tail (762-805) of ACE2. (C) Sequence of the peptide used in the holdup assay. The PBM is underlined in the sequences.

The PBM-PDZ interactions are involved in a wide variety of critical cellular processes and are often disturbed in pathologies and by viral proteins during infection. The human proteome contains $272 \mathrm{PDZ}$ domains distributed over 152 proteins, as demonstrated in Luck et al. [12], but may vary depending on databases and identification methods [13]. Recently, we used the holdup assay [14] adapted to low-to-medium (1-100 $\mu \mathrm{M})$ affinity, for high-throughput quantification of PDZ-PBM interaction to screen the PBMs of SARS-CoV-2 $\mathrm{E}, 3 \mathrm{a}$ and $\mathrm{N}$ proteins against the PDZome [15].

In this study, we used the holdup assay to identify the cellular PDZ-containing proteins targeted by ACE2 through a PDZ-PBM interaction among the full PDZome. We established a list of PDZ-containing partners potentially involved in ACE2 cell signaling through its PBM. We identified 14 PDZs that significantly bind to the ACE2 PBM and determined their affinities. Interestingly, the NHERF, SHANK and SNX27 proteins found in this study could play a role in ACE2 internalization and recycling that could benefit the virus entry. 
In addition, the ACE2 PDZ-binding motif binds notably to neuronal proteins, SHANK and MAST1/MAST2 proteins, that could participate in the neurological alterations in patients infected by SARS-CoV-2.

\section{Materials and Methods}

\subsection{Peptide Synthesis}

The biotinylated peptide (sequence Biotin-(PEG3)-GFQNTDDVQTSF) (Figure 1C) was synthesized in solid phase using Fmoc strategy (Proteogenix). The sequence encompasses a biotinyl group, a (PEG, polyethylene glycol $)_{3}$ spacer and the $\mathrm{C}$-terminal sequence of the human ACE2 protein (UniProtKB-Q9BYF1) corresponding to the last twelve residues. Peptides were resuspended in the buffer used for holdup.

\subsection{Holdup Assay}

The human PDZ domains library was produced according to the high-throughput protocol previously described [16]. Briefly, after expression of the His6-MBP-PDZ constructs in Escherichia coli and lysis of bacteria, the constructs were adjusted to a concentration of about $4 \mu \mathrm{M}$ in the soluble fractions of the cell lysate and frozen in 96-well plates.

The holdup assay was carried out as previously described [14,16]. We measured the interactions of the peptide against the complete human PDZome containing 266 PDZ domains out of 272 PDZ domains identified in the human genome [13]. Error bars are the standard deviations of two independent experiments. Briefly, cell lysates containing PDZ were incubated with streptavidin resin saturated with biotinylated PBM peptides or with biotin used as a negative control. The supernatant was separated from the resin by a rapid filtration step using filter plates and then the concentrations of PDZ in the supernatant were measured using the microcapillary electrophoretic system (Caliper; PerkinElmer, Waltham, MA, USA).

Binding intensity (BI) values were calculated using the formula: BI = (Itot - Idepl)/Itot, where Itot is the total peak intensity of PDZ (biotin control) and Idepl is the intensity of the PDZ peak in the presence of the peptide. $\mathrm{BI}=0.2$ was used as the minimum BI cutoff value to define high confidence PDZ-PBM pairs, as previously proposed [14]. For detailed protocols, see references $[14,16]$.

\subsection{Conversion of BI Values to Dissociation Equilibrium Constants}

Dissociation constants $(\mathrm{Kd})$ values were calculated from the BIs (Figure 2, Table S1) according to the method published in Gogl et al. [17].

BIs were transformed into dissociation constants (KD) using the following formula:

$$
\mathrm{Kd}=(([\mathrm{PDZtot}]-\mathrm{BI} \times[\mathrm{PDZtot}]) \times([\mathrm{PBMtot}]-\mathrm{BI} \times[\mathrm{PDZtot}])) /(\mathrm{BI} \times[\text { PDZtot }])
$$

where [PDZtot] and [PBMtot] correspond to the total concentrations of the PDZ domain (typically $4 \mu \mathrm{M}$ ) and the PBM peptide, respectively, used during the assay. The PBMtot concentration in the resin during the holdup assay may differ from one peptide to another. Thus, to convert BI values into Kd constants, we used the Kd values of the three PBM-PDZ interactions previously reported between the ACE2 PBM peptide and three PDZ domains (PDZ1 NHERF3, and the PDZ domains of SHANK1 and SNX27) measured by fluorescence polarization assays [10]. These affinities were used to back-calculate the PBM peptide concentrations in the holdup assays. We found that all determined BI-Kd pairs resulted in a mean immobilized peptide concentration of $21 \mu \mathrm{M}$, a concentration that is coherent with other peptides in the same method $[15,17,18]$. The minimal BI threshold value of 0.2 , defined for significant detectable binders, roughly corresponds to an $80 \mu \mathrm{M} \mathrm{Kd}$ value, as previously reported [15]. 


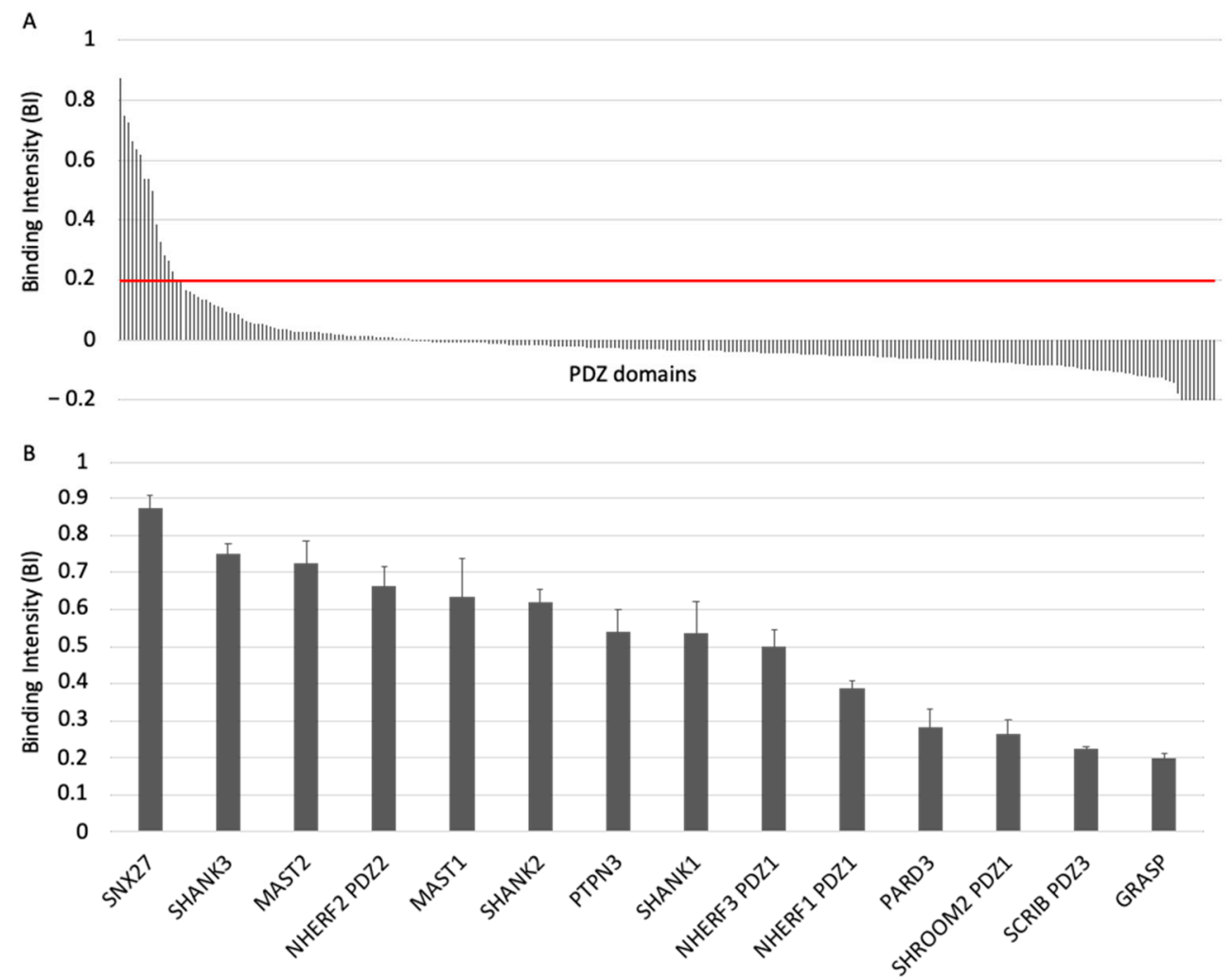

Figure 2. PDZome-binding profile of ACE2 protein PBM by holdup assay. (A) PDZ domains are ranked by decreased $B I$ values. A red line indicates the threshold of significant $B I$ at 0.2. (B) Zoomedin view shows the 14 PDZ binders of ACE2 PBM peptide, which displayed BI values higher than 0.2. The data are representative of two independent experiments and error bars correspond to the standard deviation.

\section{Results}

3.1. The ACE2 PDZ-Binding Motif Recognizes 14 PDZ Domains with Affinity Values of Interactions Ranging from $3 \mu \mathrm{M}$ to $81 \mu \mathrm{M}$

To investigate the specificity profile of the PBM of ACE2 against all human PDZ domains, we used the automated high-throughput holdup assay, which allows measuring binding intensities (BIs) for a large number of PDZ domain-PBM pairs [14]. We used an updated PDZome library that contains 266 human PDZ domains [16]. The ACE2 PBM peptide was synthetized as a 12-mer encompassing the C-terminal PBM sequence of ACE2 protein linked to an N-terminal biotinyl group (Figure $1 \mathrm{C}$ ). The PDZome-binding profile (Figure 2A) represents the individual BIs of each PDZ domain for the ACE2 PBM peptide. The binding intensities are directly linked to the PBM/PDZ affinities. Thus, the holdup approach shows a high sensitivity to detect low-to-medium affinity PDZ/PBM pairs. It provides an affinity-based ranking of the identified binders corresponding to a specificity profile (Figure 2A). Based on BI values higher than 0.2 for significant PDZpeptide interactions [14], 14 PDZ domains were identified (Figure 2B, Table S1). This dataset represents about $5 \%$ of the human PDZome targeted by the PBM of ACE2, as illustrated by the sharp profile of interaction of Figure 2A, reflecting the specificity of these interactions.

We converted the holdup BI values to $\mathrm{Kd}$ values, as described previously $[17,18]$. Using the minimal threshold $\mathrm{BI}$ value of 0.2 , corresponding to a $\mathrm{Kd}$ value of $\sim 80 \mu \mathrm{M}$ in this study, the fourteen PDZ binders of ACE2 PBM showed interactions with affinities values ranging from $3 \mu \mathrm{M}$ (SNX27) to $81 \mu \mathrm{M}$ (general receptor for phosphoinositides 1associated scaffold protein, also named Tamalin (GRASP)) (Figure 2B, Table S1). Thus, the canonical PBM sequence of ACE2 protein binds in vitro to several PDZ domains in the 
$1-100 \mu \mathrm{M}$ affinity range typically found for PDZ/PBM interactions. The PDZ of SNX27 is the best binder of ACE2 PBM in our assay, while three other PDZs present Kd values in the micromolar range: the PDZ domains of SHANK3 and of MAST2, and PDZ2 of NHERF2 (Table S1). These are considered as strong interactions for PDZ/PBM complexes. Then, the PDZ domains of MAST1, SHANK1, SHANK2, PTPN3, PARD3, GRASP, PDZ1 of NHERF3 and NHERF1 of SHROOM2 and the PDZ3 of SCRIB have intermediate Kd values between 10 and $81 \mu \mathrm{M}$ for the ACE2 PBM peptide.

\subsection{The PDZ-Binding Motif of ACE2 Targets Proteins Involved in Protein Trafficking and Some Proteins Preferentially Expressed in Neurons}

We determined a list of PDZ-containing partners potentially targeted by ACE2 in cells. We investigated their roles and searched for potential links with ACE2 and/or SARS-CoV-2 infection.

SNX27 was the best binder of ACE2 PBM in our holdup assay. This binding was previously reported by Kliche et al. [10]. SNX27 belongs to the sorting nexin family of proteins and is involved in the recycling of internalized transmembrane proteins [19]. SNX27 is widely expressed but has been extensively studied in the context of the central nervous system (CNS) homeostasis regulation [20]. SNX27 is important for higher-order processes, such as learning and memory [21], and patients with SNX27 variants display seizures, developmental delay, behavioral disturbance and subcortical brain abnormalities [22].

SHANK1, SHANK2 and SHANK3 are targeted by the ACE2 PBM and belong to the SHANK family composed of developmental genes involved in the development and function of neural circuits, as well as in the formation of synapses. Mutations in SHANK genes involve autism spectrum disorder with altered functions in synaptic scaffolding to regulating spine morphology and neurotransmission [23].

The three members of the NHERF family, NHERF1, NHERF2 and NHERF3, are also targeted by the PBM of ACE2. The NHERF family functions are broad [24]. These scaffold proteins contain two PDZ domains and a C-terminal sequence that binds several members of the ERM (ezrin-radixin-moesin) family and they are highly expressed in epithelial tissues [25]. Many NHERF partners have been identified, broadening the protein functions in membrane physiology. NHERF is involved in transporting proteins to apical membranes and in the regulation of endocytosis and internal trafficking of membrane proteins [26]. NHERF1 was recently shown to interact through PDZ/PBM interaction with ACE2. Zhang et al. proposed that this interaction facilitates ACE2 receptor internalization and thus SARS-CoV-2 virion internalization, since it is attached through ACE2 by the viral surface spike protein [11].

Then, two members of the MAST family, MAST1 and MAST2, are targeted by the PBM of ACE2. The MAST family is composed of five genes (MAST1, MAST2, MAST3, MAST4, and MASTL) and is predominantly expressed in neuronal cells [27]. It forms a subgroup of microtubule-associated serine/threonine kinases composed of a kinase domain and a PDZ domain. They are involved in microtubule assembly, an essential step in neurogenesis. MAST1 is essential for correct brain development [28] and MAST1 substitutions are present in patients with autism and microcephaly, suggesting that mutations in this gene might be involved in neurodevelopmental diseases. MAST2 is an anti-survival kinase that interacts with PTEN in neurons [29] among other roles. MAST2 shows an association with red blood cell distribution width, which was identified recently as a biomarker of COVID-19 mortality [30]. MAST3 may play a role in developmental and epileptic encephalopathies [31].

PTPN3 is a tyrosine phosphatase, the vertebrate homolog of Ptpmeg, expressed among others in the nervous system and involved in neuronal circuit formation in the drosophila central brain [32]. PTPN3 is also often found involved in a variety of human cancers [33].

PARD3 is essential in epithelial tight junctions. It is required for the establishment of neuronal polarity and normal axon formation in cultured hippocampal neurons $[34,35]$. Interestingly, we previously showed that it is a potential target of the SARS-CoV-2 envelope 
PBM [15]. SCRIB is a polarity protein important in maintaining cell junctions and belongs to polarity complexes as PARD3.

SHROOM2 may be involved in endothelial cell morphology changes during cell spreading [36] and GRASP regulates the trafficking of metabotropic glutamate receptors that play important roles in various neuronal functions [37].

Hence, 9 out of 14 proteins have been described to play a role in neuronal cells depicting a neuronal-oriented specificity profile with a significant emphasis on cellular junctions and trafficking.

\section{Discussion}

ACE2 is involved in blood pressure regulation and cleaves a range of substrates involved in different physiological processes. ACE2 receptors, proteases such TMPRSS2, and furin are important for viral entry into host cells for coronaviruses such as SARS-CoV-2. Importantly, ACE2 is the functional receptor for SARS-CoV-2 responsible for the COVID19 disease. ACE2 belongs to a family of transmembrane proteins that have wide tissue distribution. Protein expression of ACE2 was initially identified in the heart, kidney, and testis, and on the surface of cells that are in contact with the cellular environment such as the lung's alveolar epithelial cells and the small intestine's enterocytes. In addition, ACE2 is also localized in the brain [38,39].

In this work, we demonstrated that a peptide mimicking the C-terminal sequence of ACE2 containing a three-residue canonical class I PBM binds in vitro to several human PDZ domains. Fourteen PDZ domains (5\% of the human PDZome) were identified as binders of the ACE2 PBM with $\mathrm{Kd}$ values ranging from $3 \mu \mathrm{M}$ to $81 \mu \mathrm{M}$.

The 14 PDZ-PBM interactions found in this study may impact the SARS-CoV-2 viral infection, as recently observed for NHERF1 and SNX27. In this case, the PDZ/PBM interaction of ACE2 with NHERF1 facilitates SARS-CoV-2 internalization by enhancing the ACE2 membrane residence [11]. Interestingly, the four PDZ-containing proteins, PARD3, NHERF1, MAST2 and SNX27, were also identified as binders of the class II PBM of the envelope (E) protein of SARS-CoV-2 in our previous study [15] due to the prominent promiscuity of PDZ domains. Among these binders, we showed that PARD3 and MAST2 significantly affect viral replication under knock down gene expression in infected cells. This suggests that SARS-CoV-2 also targets ACE2 partners to potentially facilitate virus entry. NHERF, SHANK, and SNX27 proteins are involved in receptor trafficking both at the cell surface and intracellular side, which could be linked to the recycling of ACE2. SNX27 is involved in transport by the recycling of internalized transmembrane proteins [40]. It is required for SARS-CoV-2 entry [41]. Thus, SNX27 might be involved in recycling ACE2 to the plasma membrane stimulating viral entry, as previously suggested by Kliche et al. [10]. Interestingly, SNX27 was recently reported to interact with the SARS-CoV-2 spike (S) protein through its PDZ domain to facilitate $S$ protein surface expression, although the viral protein does not contain a PBM. SARS-CoV-2 may facilitate virion trafficking to establish virus infection by this strategy [42]. Overall, among the ACE2 binders, some are known to interact with viruses such as SNX27 [43,44], MAST2, PTPN3 and SCRIB [45]. Particular attention must be paid to the cellular context because of possible different localization of the PBM-containing protein and the PDZ proteins, the level of cellular expression and the potential post-translational modifications that can affect the interaction. Future works should investigate these aspects.

The NHERF family is also a potential target of the ACE2 PBM. NHERF2 is structurally related to NHERF1. NHERF3 regulates the surface expression of plasma membrane proteins in the apical area of epithelial cells in agreement with the enrichment of ACE2 on the apical surface of airway epithelia [46]. Thus, PDZ/PBM interactions can play a role in ACE2 localization and recycling, which could be beneficial for the virus for internalization.

We found that nine PDZ-containing proteins targeted by ACE2 PBM display neuronal functions: the three SHANK, two MAST proteins, SNX27, PARD3, GRASP and PTPN3. Interestingly, the human PDZ specificity profiles we previously established for 
neurotropic viruses with the PBMs of the Rabies glycoprotein and of the West Nile NS5 protein mainly overlap with the PDZ profile we showed in this study [47,48]. ACE2 in the CNS is involved in the regulation of cardiovascular function and has noticeable effects on blood pressure, cardiac hypertrophy, stress response, anxiety, cognition, brain injury and neurogenesis [49,50]. ACE2 may play a role in the CNS through the PBM-PDZ interactions with the nine PDZ-containing proteins, with neuronal functions found to interact with its PBM. Interestingly, SARS-CoV-2 affects multiple organ systems, including the CNS. Most patients with COVID-19, caused by SARS-CoV-2, exhibit neurological symptoms. Neurons can be a target of SARS-CoV-2 infection, with localized ischemia in the brain and cell death, highlighting that SARS-CoV-2 neurotropism and neuronal infection can be prevented by blocking ACE2 with antibodies [51]. Indeed, the ACE2 receptor is expressed in the brain by endothelial, neuronal and glial cells. After the spreading of the virus to CNS, it comes into contact with ACE2 on neurons, glia and vascular endothelium [52]. SARS-CoV-2 might also interact directly with sensory neurons, given that sensory dysfunction, including cough, olfactory and taste impairments, are frequent in infected patients [53,54]. Recently, the loss of the cilia allowing the reception of odor molecules by sensory neurons has been reported after viral infection as well as the presence of viruses in sensory neurons. In addition, the virus invasion in the olfactory bulb as well as the presence of neuroinflammation and viral RNA in several regions of the brain have been shown [54].

Thus, we identified proteins potentially targeted by ACE2 providing new cellular protein partners through PDZ-PBM interactions. Recent proteomics of SARS-CoV-2infected host cells did not allow us to correlate the expression of these PDZ-containing partners with the ACE2 expression profile [55]. Our study provides a resource for the research on possible biological pathways involving ACE2. Moreover, SARS-CoV-2 enters the cells through the widely expressed ACE2 receptor, affects organ systems including the CNS and it therefore has pleiotropic effects. Modifications of the interactions between ACE2 and the neuronal proteins identified in our assay could participate in the neurological alterations observed in COVID-19.

Supplementary Materials: The following are available online at https:/ /www.mdpi.com/article/ 10.3390/v13112281/s1, Table S1: All BI values obtained by holdup assay using PBM peptide from ACE2 protein. Negative BI values reflect the error and limit of detection of significant PDZ/peptide interactions as previously reported [14].

Author Contributions: C.C.-S. and N.W. planned the experiments. C.C.-S. performed the experiments. C.C.-S. and N.W. analyzed the data. C.C.-S. and N.W. wrote the paper. All authors have read and agreed to the published version of the manuscript.

Funding: This research was funded by the URGENCE COVID-19 fundraising campaign of the Institut Pasteur and the ANR Recherche Action COVID-19-FRM PDZCov2 program.

Institutional Review Board Statement: Not applicable.

Informed Consent Statement: Not applicable.

Conflicts of Interest: The authors declare no conflict of interest.

\section{References}

1. Wang, Q.; Zhang, Y.; Wu, L.; Niu, S.; Song, C.; Zhang, Z.; Lu, G.; Qiao, C.; Hu, Y.; Yuen, K.-Y.; et al. Structural and Functional Basis of SARS-CoV-2 Entry by Using Human ACE2. Cell 2020, 181, 894-904.e9. [CrossRef]

2. Hoffmann, M.; Kleine-Weber, H.; Schroeder, S.; Krüger, N.; Herrler, T.; Erichsen, S.; Schiergens, T.S.; Herrler, G.; Wu, N.-H.; Nitsche, A.; et al. SARS-CoV-2 Cell Entry Depends on ACE2 and TMPRSS2 and Is Blocked by a Clinically Proven Protease Inhibitor. Cell 2020, 181, 271-280.e8. [CrossRef]

3. Koppisetti, R.K.; Fulcher, Y.G.; Van Doren, S.R. Fusion Peptide of SARS-CoV-2 Spike Rearranges into a Wedge Inserted in Bilayered Micelles. J. Am. Chem. Soc. 2021, 143, 13205-13211. [CrossRef] [PubMed]

4. Fehr, A.R.; Perlman, S. Coronaviruses: An Overview of Their Replication and Pathogenesis. Methods Mol. Biol. 2015, 1282, 1-23. [CrossRef] [PubMed] 
5. Vianello, A.; Del Turco, S.; Babboni, S.; Silvestrini, B.; Ragusa, R.; Caselli, C.; Melani, L.; Fanucci, L.; Basta, G. The Fight against COVID-19 on the Multi-Protease Front and Surroundings: Could an Early Therapeutic Approach with Repositioning Drugs Prevent the Disease Severity? Biomedicines 2021, 9, 710. [CrossRef] [PubMed]

6. V'kovski, P.; Kratzel, A.; Steiner, S.; Stalder, H.; Thiel, V. Coronavirus Biology and Replication: Implications for SARS-CoV-2. Nat. Rev. Microbiol. 2020, 19, 155-170. [CrossRef] [PubMed]

7. Li, M.-Y.; Li, L.; Zhang, Y.; Wang, X.-S. Expression of the SARS-CoV-2 Cell Receptor Gene ACE2 in a Wide Variety of Human Tissues. Infect. Dis. Poverty 2020, 9, 45. [CrossRef] [PubMed]

8. Lukassen, S.; Chua, R.L.; Trefzer, T.; Kahn, N.C.; Schneider, M.A.; Muley, T.; Winter, H.; Meister, M.; Veith, C.; Boots, A.W.; et al. SARS-CoV-2 Receptor ACE2 and TMPRSS2 Are Primarily Expressed in Bronchial Transient Secretory Cells. EMBO J. 2020, 39, e105114. [CrossRef] [PubMed]

9. Mészáros, B.; Sámano-Sánchez, H.; Alvarado-Valverde, J.; Čalyševa, J.; Martínez-Pérez, E.; Alves, R.; Shields, D.C.; Kumar, M.; Rippmann, F.; Chemes, L.B.; et al. Short Linear Motif Candidates in the Cell Entry System Used by SARS-CoV-2 and Their Potential Therapeutic Implications. Sci. Signal. 2021, 14. [CrossRef]

10. Kliche, J.; Kuss, H.; Ali, M.; Ivarsson, Y. Cytoplasmic Short Linear Motifs in ACE2 and Integrin B3 Link SARS-CoV-2 Host Cell Receptors to Mediators of Endocytosis and Autophagy. Sci. Signal. 2021, 14. [CrossRef]

11. Zhang, Q.; Gefter, J.; Sneddon, W.B.; Mamonova, T.; Friedman, P.A. ACE2 Interaction with Cytoplasmic PDZ Protein Enhances SARS-CoV-2 Invasion. iScience 2021, 24, 102770. [CrossRef]

12. Luck, K.; Charbonnier, S.; Travé, G. The Emerging Contribution of Sequence Context to the Specificity of Protein Interactions Mediated by PDZ Domains. FEBS Lett. 2012, 586, 2648-2661. [CrossRef]

13. Amacher, J.F.; Brooks, L.; Hampton, T.H.; Madden, D.R. Specificity in PDZ-Peptide Interaction Networks: Computational Analysis and Review. J. Struct. Biol. X 2020, 4, 100022. [CrossRef] [PubMed]

14. Vincentelli, R.; Luck, K.; Poirson, J.; Polanowska, J.; Abdat, J.; Blémont, M.; Turchetto, J.; Iv, F.; Ricquier, K.; Straub, M.-L.; et al. Quantifying Domain-Ligand Affinities and Specificities by High-Throughput Holdup Assay. Nat. Methods 2015, 12, 787-793. [CrossRef]

15. Caillet-Saguy, C.; Durbesson, F.; Rezelj, V.V.; Gogl, G.; Tran, Q.D.; Twizere, J.-C.; Vignuzzi, M.; Vincentelli, R.; Wolff, N. Host PDZ-Containing Proteins Targeted by SARS-CoV-2. FEBS J. 2021, 288, 5148-5162. [CrossRef]

16. Duhoo, Y.; Girault, V.; Turchetto, J.; Ramond, L.; Durbesson, F.; Fourquet, P.; Nominé, Y.; Cardoso, V.; Sequeira, A.F.; Brás, J.L.A.; et al. High-Throughput Production of a New Library of Human Single and Tandem PDZ Domains Allows Quantitative PDZ-Peptide Interaction Screening Through High-Throughput Holdup Assay. Methods Mol. Biol. Clifton NJ 2019, 2025, 439-476. [CrossRef]

17. Gogl, G.; Jane, P.; Caillet-Saguy, C.; Kostmann, C.; Bich, G.; Cousido-Siah, A.; Nyitray, L.; Vincentelli, R.; Wolff, N.; Nomine, Y.; et al. Dual Specificity PDZ- and 14-3-3-Binding Motifs: A Structural and Interactomics Study. Struct. Lond. Engl. 1993 2020, 28, 747-759.e3. [CrossRef]

18. Jané, P.; Gógl, G.; Kostmann, C.; Bich, G.; Girault, V.; Caillet-Saguy, C.; Eberling, P.; Vincentelli, R.; Wolff, N.; Travé, G.; et al. Interactomic Affinity Profiling by Holdup Assay: Acetylation and Distal Residues Impact the PDZome-Binding Specificity of PTEN Phosphatase. PLoS ONE 2020, 15, e0244613. [CrossRef] [PubMed]

19. Steinberg, F.; Gallon, M.; Winfield, M.; Thomas, E.C.; Bell, A.J.; Heesom, K.J.; Tavaré, J.M.; Cullen, P.J. A Global Analysis of SNX27-Retromer Assembly and Cargo Specificity Reveals a Function in Glucose and Metal Ion Transport. Nat. Cell Biol. 2013, 15, 461-471. [CrossRef] [PubMed]

20. Halff, E.F.; Szulc, B.R.; Lesept, F.; Kittler, J.T. SNX27-Mediated Recycling of Neuroligin-2 Regulates Inhibitory Signaling. Cell Rep. 2019, 29, 2599-2607.e6. [CrossRef] [PubMed]

21. Wang, X.; Zhao, Y.; Zhang, X.; Badie, H.; Zhou, Y.; Mu, Y.; Loo, L.S.; Cai, L.; Thompson, R.C.; Yang, B.; et al. Loss of Sorting Nexin 27 Contributes to Excitatory Synaptic Dysfunction by Modulating Glutamate Receptor Recycling in Down's Syndrome. Nat. Med. 2013, 19, 473-480. [CrossRef] [PubMed]

22. Parente, D.J.; Morris, S.M.; McKinstry, R.C.; Brandt, T.; Gabau, E.; Ruiz, A.; Shinawi, M. Sorting Nexin 27 (SNX27) Variants Associated with Seizures, Developmental Delay, Behavioral Disturbance, and Subcortical Brain Abnormalities. Clin. Genet. 2020, 97, 437-446. [CrossRef] [PubMed]

23. Monteiro, P.; Feng, G. SHANK Proteins: Roles at the Synapse and in Autism Spectrum Disorder. Nat. Rev. Neurosci. 2017, 18, 147-157. [CrossRef]

24. Weinman, E.J. New Functions for the NHERF Family of Proteins. J. Clin. Investig. 2001, 108, 185-186. [CrossRef] [PubMed]

25. Voltz, J.W.; Weinman, E.J.; Shenolikar, S. Expanding the Role of NHERF, a PDZ-Domain Containing Protein Adapter, to Growth Regulation. Oncogene 2001, 20, 6309-6314. [CrossRef]

26. Shenolikar, S.; Weinman, E.J. NHERF: Targeting and Trafficking Membrane Proteins. Am. J. Physiol. Ren. Physiol. 2001, 280, F389-395. [CrossRef] [PubMed]

27. Garland, P.; Quraishe, S.; French, P.; O'Connor, V. Expression of the MAST Family of Serine/Threonine Kinases. Brain Res. 2008, 1195, 12-19. [CrossRef]

28. Tripathy, R.; Leca, I.; van Dijk, T.; Weiss, J.; van Bon, B.W.; Sergaki, M.C.; Gstrein, T.; Breuss, M.; Tian, G.; Bahi-Buisson, N.; et al Mutations in MAST1 Cause Mega-Corpus-Callosum Syndrome with Cerebellar Hypoplasia and Cortical Malformations. Neuron 2018, 100, 1354-1368.e5. [CrossRef] 
29. Terrien, E.; Chaffotte, A.; Lafage, M.; Khan, Z.; Préhaud, C.; Cordier, F.; Simenel, C.; Delepierre, M.; Buc, H.; Lafon, M.; et al. Interference with the PTEN-MAST2 Interaction by a Viral Protein Leads to Cellular Relocalization of PTEN. Sci. Signal. 2012, 5, ra58. [CrossRef]

30. Foy, B.H.; Carlson, J.C.T.; Reinertsen, E.; Padros I Valls, R.; Pallares Lopez, R.; Palanques-Tost, E.; Mow, C.; Westover, M.B.; Aguirre, A.D.; Higgins, J.M. Association of Red Blood Cell Distribution Width with Mortality Risk in Hospitalized Adults with SARS-CoV-2 Infection. JAMA Netw. Open 2020, 3, e2022058. [CrossRef]

31. Spinelli, E.; Christensen, K.R.; Bryant, E.; Schneider, A.; Rakotomamonjy, J.; Muir, A.M.; Giannelli, J.; Littlejohn, R.O.; Roeder, E.R.; Schmidt, B.; et al. Pathogenic MAST3 Variants in the STK Domain Are Associated with Epilepsy. Ann. Neurol. 2021, 90, 274-284. [CrossRef]

32. Whited, J.L.; Robichaux, M.B.; Yang, J.C.; Garrity, P.A. Ptpmeg Is Required for the Proper Establishment and Maintenance of Axon Projections in the Central Brain of Drosophila. Dev. Camb. Engl. 2007, 134, 43-53. [CrossRef]

33. Hendriks, W.J.A.J.; Böhmer, F.-D. Non-Transmembrane PTPs in Cancer. In Protein Tyrosine Phosphatases in Cancer; Neel, B.G., Tonks, N.K., Eds.; Springer: Berlin/Heidelberg, Germany, 2016; ISBN 978-1-4939-3649-6.

34. Khazaei, M.R.; Püschel, A.W. Phosphorylation of the Par Polarity Complex Protein Par3 at Serine 962 Is Mediated by Aurora a and Regulates Its Function in Neuronal Polarity. J. Biol. Chem. 2009, 284, 33571-33579. [CrossRef] [PubMed]

35. Chen, X.; An, Y.; Gao, Y.; Guo, L.; Rui, L.; Xie, H.; Sun, M.; Lam Hung, S.; Sheng, X.; Zou, J.; et al. Rare Deleterious PARD3 Variants in the APKC-Binding Region Are Implicated in the Pathogenesis of Human Cranial Neural Tube Defects Via Disrupting Apical Tight Junction Formation. Hum. Mutat. 2017, 38, 378-389. [CrossRef] [PubMed]

36. Farber, M.J.; Rizaldy, R.; Hildebrand, J.D. Shroom2 Regulates Contractility to Control Endothelial Morphogenesis. Mol. Biol. Cell 2011, 22, 795-805. [CrossRef]

37. Pandey, S.; Ramsakha, N.; Sharma, R.; Gulia, R.; Ojha, P.; Lu, W.; Bhattacharyya, S. The Post-Synaptic Scaffolding Protein Tamalin Regulates Ligand-Mediated Trafficking of Metabotropic Glutamate Receptors. J. Biol. Chem. 2020, 295, 8575-8588. [CrossRef] [PubMed]

38. Doobay, M.F.; Talman, L.S.; Obr, T.D.; Tian, X.; Davisson, R.L.; Lazartigues, E. Differential Expression of Neuronal ACE2 in Transgenic Mice with Overexpression of the Brain Renin-Angiotensin System. Am. J. Physiol. Regul. Integr. Comp. Physiol. 2007, 292, R373-381. [CrossRef]

39. Pacheco-Herrero, M.; Soto-Rojas, L.O.; Harrington, C.R.; Flores-Martinez, Y.M.; Villegas-Rojas, M.M.; León-Aguilar, A.M.; Martínez-Gómez, P.A.; Campa-Córdoba, B.B.; Apátiga-Pérez, R.; Corniel-Taveras, C.N.; et al. Elucidating the Neuropathologic Mechanisms of SARS-CoV-2 Infection. Front. Neurol. 2021, 12, 660087. [CrossRef]

40. Lauffer, B.E.L.; Melero, C.; Temkin, P.; Lei, C.; Hong, W.; Kortemme, T.; von Zastrow, M. SNX27 Mediates PDZ-Directed Sorting from Endosomes to the Plasma Membrane. J. Cell Biol. 2010, 190, 565-574. [CrossRef]

41. Zhu, Y.; Feng, F.; Hu, G.; Wang, Y.; Yu, Y.; Zhu, Y.; Xu, W.; Cai, X.; Sun, Z.; Han, W.; et al. A Genome-Wide CRISPR Screen Identifies Host Factors That Regulate SARS-CoV-2 Entry. Nat. Commun. 2021, 12, 961. [CrossRef]

42. Zhao, L.; Zhong, K.; Zhao, J.; Yong, X.; Tong, A.; Jia, D. SARS-CoV-2 Spike Protein Harnesses SNX27-mediated Endocytic Recycling Pathway. MedComm 2021, mco2.92. [CrossRef]

43. Al-Saleem, J.; Dirksen, W.P.; Martinez, M.P.; Shkriabai, N.; Kvaratskhelia, M.; Ratner, L.; Green, P.L. HTLV-1 Tax-1 Interacts with SNX27 to Regulate Cellular Localization of the HTLV-1 Receptor Molecule, GLUT1. PLoS ONE 2019, 14, e0214059. [CrossRef]

44. Ganti, K.; Massimi, P.; Manzo-Merino, J.; Tomaić, V.; Pim, D.; Playford, M.P.; Lizano, M.; Roberts, S.; Kranjec, C.; Doorbar, J.; et al. Interaction of the Human Papillomavirus E6 Oncoprotein with Sorting Nexin 27 Modulates Endocytic Cargo Transport Pathways. PLoS Pathog. 2016, 12, e1005854. [CrossRef] [PubMed]

45. Javier, R.T.; Rice, A.P. Emerging Theme: Cellular PDZ Proteins as Common Targets of Pathogenic Viruses. J. Virol. 2011, 85, 11544-11556. [CrossRef] [PubMed]

46. Jia, H.P.; Look, D.C.; Shi, L.; Hickey, M.; Pewe, L.; Netland, J.; Farzan, M.; Wohlford-Lenane, C.; Perlman, S.; McCray, P.B. ACE2 Receptor Expression and Severe Acute Respiratory Syndrome Coronavirus Infection Depend on Differentiation of Human Airway Epithelia. J. Virol. 2005, 79, 14614-14621. [CrossRef] [PubMed]

47. Khan, Z.; Terrien, E.; Delhommel, F.; Lefebvre-Omar, C.; Bohl, D.; Vitry, S.; Bernard, C.; Ramirez, J.; Chaffotte, A.; Ricquier, K.; et al. Structure-Based Optimization of a PDZ-Binding Motif within a Viral Peptide Stimulates Neurite Outgrowth. J. Biol. Chem. 2019, 294, 13755-13768. [CrossRef] [PubMed]

48. Giraud, E.; Del Val, C.O.; Caillet-Saguy, C.; Zehrouni, N.; Khou, C.; Caillet, J.; Jacob, Y.; Pardigon, N.; Wolff, N. Role of PDZ-Binding Motif from West Nile Virus NS5 Protein on Viral Replication. Sci. Rep. 2021, 11, 3266. [CrossRef]

49. Xia, H.; Lazartigues, E. Angiotensin-Converting Enzyme 2 in the Brain: Properties and Future Directions. J. Neurochem. 2008, 107, 1482-1494. [CrossRef] [PubMed]

50. Alenina, N.; Bader, M. ACE2 in Brain Physiology and Pathophysiology: Evidence from Transgenic Animal Models. Neurochem. Res. 2019, 44, 1323-1329. [CrossRef]

51. Song, E.; Zhang, C.; Israelow, B.; Lu-Culligan, A.; Prado, A.V.; Skriabine, S.; Lu, P.; Weizman, O.-E.; Liu, F.; Dai, Y.; et al. Neuroinvasion of SARS-CoV-2 in Human and Mouse Brain. J. Exp. Med. 2021, 218, e20202135. [CrossRef]

52. Engin, A.B.; Engin, E.D.; Engin, A. Current Opinion in Neurological Manifestations of SARS-CoV-2 Infection. Curr. Opin. Toxicol. 2021, 25, 49-56. [CrossRef] [PubMed] 
53. Menni, C.; Valdes, A.M.; Freidin, M.B.; Sudre, C.H.; Nguyen, L.H.; Drew, D.A.; Ganesh, S.; Varsavsky, T.; Cardoso, M.J.; El-Sayed Moustafa, J.S.; et al. Real-Time Tracking of Self-Reported Symptoms to Predict Potential COVID-19. Nat. Med. 2020, 26, 1037-1040. [CrossRef] [PubMed]

54. De Melo, G.D.; Lazarini, F.; Levallois, S.; Hautefort, C.; Michel, V.; Larrous, F.; Verillaud, B.; Aparicio, C.; Wagner, S.; Gheusi, G.; et al. COVID-19-Associated Olfactory Dysfunction Reveals SARS-CoV-2 Neuroinvasion and Persistence in the Olfactory System. Sci. Transl. Med. 2021, 13, eabf8396. [CrossRef] [PubMed]

55. Bojkova, D.; Klann, K.; Koch, B.; Widera, M.; Krause, D.; Ciesek, S.; Cinatl, J.; Münch, C. Proteomics of SARS-CoV-2-Infected Host Cells Reveals Therapy Targets. Nature 2020, 583, 469-472. [CrossRef] 